\title{
Materiaey
}

KLIO. Czasopismo poświęcone dziejom Polski i powszechnym

PL ISSN 1643-8191, t. 20 (1) 2012, s. 235-250

Slawomir Wróblewski

(Kraków)

\section{Staropolskie akta miasta Wieliczki w zasobie Archiwum Państwowego w Krakowie}

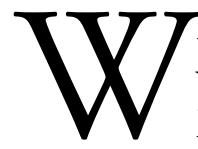

ieliczka, stanowiąc znaczący ośrodek górnictwa solnego, przez wieki słynęła szeroko i cieszyła się w regionie szczególną rangą. Miasto z racji na swoje wyjątkowe znaczenie w krajowej gospodarce hojnie obdarzane było królewskimi przywilejami, co wydatnie wspomagało jego rozwój, szczególnie od czasów Kazimierza Wielkiego, a zwieńczony okresem największej pomyślności w latach panowania dwóch ostatnich Jagiellonów ${ }^{1}$ Z racji na tę pozycję i gospodarczą rolę Wieliczki naturalną koleją rzeczy jej dzieje stanowią od dawna istotny obiekt zainteresowań badaczy przeszłości, napotykających niestety na trudność, którą wobec dawnego znaczenia miasta uważać można za niespodziewaną, a jest nią szczupłość istniejących historycznych źródeł.

Staropolskie akta miejskie Wieliczki do naszych czasów zachowały się w stanie szczątkowym; przepadła niemal całość materiałów wytworzonych przez kancelarię miejską. Dysponujemy dziś jedynie kilkoma wielickimi księgami wpisów z XVI-XVIII w. oraz pochodzącymi w przeważającej części z XVII stulecia silnie zniszczonymi fragmentami kolejnych dwóch, a ponadto pewną liczbą rozproszonych, zachowanych $\mathrm{w}$ formie oryginałów i w różnego typu odpisach i wypisach innych aktów. Lepiej zachowane są wielickie

1 K. Pająk, Wieliczka. Stare miasto górnicze, Kraków 1968, s. 23-55. 
przywileje i inne odnoszące się do miasta dyplomy, których w sumie przetrwało kilkadziesiąt. Zachowało się nieco akt działających w Wieliczce cechów ${ }^{2}$.

Niezbyt jasno przedstawiają się okoliczności zniszczenia wielickich akt miejskich; wiemy tyle, że ich przepadek nastąpił co najmniej dwukrotnie. Po raz pierwszy księgi strawił pożar w 1556 r.; te wpisy z ksiąg ławniczych, które dotyczyły spraw własnościowych, starano się potem zrekonstruować ${ }^{3}$, lecz późniejsze księgi również nie przetrwały i właśnie okoliczności ich utraty, z racji na brak jasnych informacji źródłowych musimy się domyślać. Najpewniej miejskie akta uległy ponownie zniszczeniu w 1877 r., kiedy to w innym pożarze miasta spłonął m.in. budynek magistratu ${ }^{4}$, chociaż niewykluczone, że jakaś część z nich spłonęła już w którymś z wcześniejszych, często nękających miasto pożarów 5 . Szczęśliwie natomiast ocalała do dziś znaczna liczba oryginalnych dokumentów wielickich, które jeszcze w 1873 r. przekazane zostały przez magistrat Bibliotece Jagiellońskiej i aktualnie znajdują się w jej zbiorach ${ }^{6}$. Zauważyć można, że Wieliczka nie jest w swojej sytuacji odosobniona. Znamy i przecież inne przypadki ośrodków, także i takich w prze-

2 Brak większości akt miejskich Wieliczki w pewnym stopniu rekompensuje fakt, że równocześnie rzucają nieco światła na dzieje miasta akta krakowskich żup solnych, na które dla okresu przedrozbiorowego składają się takie dokumenty, jak królewskie dyplomy dotyczące nadań solnych i immunitetów, akty normatywne regulujące organizację żup, kontrakty dzierżaw, księgi rachunkowe i inne akta wytwarzane przez administrację żup, jak również przez organy kontrolujące eksploatację soli i handel nią. Ogólny przegląd źródeł do dziejów żup solnych krakowskich oraz miejsc ich przechowywania dał Antoni Jodłowski (A. Jodłowski, Ogólna charakterystyka stanu badań, źródet i opracowań, [w:] Dzieje żup krakowskich, red. A. Jodłowski i in., Wieliczka 1988, s. 20-35).

3 J. Piotrowicz, Dole i niedole Wieliczki za panowania ostatnich Jagiellonów i królów elekcyjnych (do "potopu” szwedzkiego), [w:] Wieliczka. Dzieje miasta (do roku 1980), red. S. Gawęda, A. Jodłowski, J. Piotrowicz, Kraków 1990, s. 132.

4 S. Gawęda, Wieliczka pod rządami austriackimi (1772-1918), [w:] Wieliczka. Dzieje miasta, s. 213.

${ }_{5}$ Za przekazanie informacji na temat okoliczności zniszczenia wielickich archiwaliów dziękuję Pani kierownik Działu Historycznego Muzeum Żup Krakowskich w Wieliczce mgr Małgorzacie Międzobrodzkiej.

6 Inwentarz rękopisów Biblioteki Jagiellońskiej. Nr 7001-8000, cz. 2, opr. A. Jabłrzykowska, Kraków 1966, s. 38. Dyplomy te przekazane zostały Bibliotece Jagiellońskiej po uprzednim wydaniu ich drukiem, pod auspicjami hr. Agenora Gołuchowskiego, w 1872 r. W sporządzonym wówczas kodeksie dyplomatycznym zawarto te i inne dokumenty z lat 1290-1765; zob. Kodex Dyplomatyczny Wielicki, wydany z polecenia Jego Excellencyi Hrabiego Agenora Gotuchowskiego, Lwów 1872. 
szłości znaczących, które w pożogach straciły znaczną część swoich archiwaliów. Wymienić tu można chociażby inne małopolskie miasto - Nowy Sącz, przy czym z pożaru, który w 1894 r. strawił m.in. tamtejszy ratusz, udało się uratować odwrotnie niż w przypadku Wieliczki księgi ławnicze i radzieckie, a spłonęły wówczas wszystkie przywileje pergaminowe (zresztą w wielkiej liczbie, bo ok. 300 dokumentów) ${ }^{7}$.

Akta miasta Wieliczki, które się do dziś dochowały, odnaleźć można w kilku archiwach i bibliotekach, przede wszystkim krakowskich i wielickich, chociaż nie wyłącznie. Najznaczniejszą i bodaj najcenniejszą ich część znajdziemy w Bibliotece Jagiellońskiej, która przejęła m.in. wielickie dyplomy pergaminowe, ponadto, już co prawda zachowane szczątkowo, nieraz jednak interesujące akta Wieliczki przechowują m.in. Archiwum Muzeum Żup Krakowskich, Biblioteka Naukowa Polskiej Akademii Umiejętności i Polskiej Akademii Nauk w Krakowie, czy też Biblioteka Fundacji Książąt Czartoryskich w Krakowie. Staropolskie akta wielickie znajdują się także w zasobie Archiwum Państwowego w Krakowie i stanowią one również materiał zachowany szczątkowo, jednak z racji swej różnorodności warte są bliższej uwagi, tym bardziej że na zasadniczą część z nich, zewidencjonowaną w zespole Akt miasta Wieliczki pewne nowe światło rzuciło niedawno przeprowadzone jej opracowanie. Zarazem interesujące nas, znajdujące się w zbiorach pozostałych wymienionych instytucji, akta ujęte są w wydanych drukiem inwentarzach, $\mathrm{z}$ wyjątkiem jedynie specjalnie skądinąd cennego zbioru pergaminów Biblioteki Jagiellońskiej, który również posiada dokładną ewidencję, zatem obecność archiwaliów wielickich w krakowskich bibliotekach i archiwach wielickich będzie poniżej tylko zasygnalizowana, natomiast bliższa uwaga poświęcona zostanie aktom przechowywanym w zasobie Archiwum Państwowego w Krakowie.

Jak wyżej wspomniano sporo szczególnie cennych dokumentów uzyskała w XIX w. Biblioteka Jagiellońska i tam też są one nadal przechowywane. Stanowi je ponad pięćdziesiąt pochodzących z lat 1290-1739, odnoszących się do spraw Wieliczki dyplomów pergaminowych, z których przeważająca część to dokumenty przejęte z tamtejszego magistratu w 1873 r. (w tym m.in. najdawniejszy dyplom, wydany przez Przemysła II z 1290 r., na mocy

7 K. Golachowski, Inwentarz archiwum miasta Nowego Sacza z lat 1292-1772, „Rocznik Sądecki” 1957, t. 3, s. 190-191; z tym że uratowane nowosądeckie księgi miejskie także dalekie są od kompletności, najstarsza ich część spłonęła bowiem w pożarze miasta w 1486 r., zob. ibidem, s. 184. 
którego książę potwierdził Wieliczce przywilej lokacyjny nadany jej przez Henryka Probusa $)^{8}$. W zbiorach Biblioteki Jagiellońskiej przechowywane są również inne wielickie archiwalia, jak statuty, dekrety, listy królewskie, wypisy z ksiąg sądowych, kopie przywilejów, etc. z lat 1381-1765, które odnaleźć można w kilku rękopisach. W całości sprawom wielickim - miastu, mieszczanom, a w mniejszym stopniu również żupom solnym poświęcony jest plik akt papierowych, które przekazane zostały Bibliotece Jagiellońskiej z wielickiego Archiwum wraz z dokumentami pergaminowymi w 1873 r., a aktualnie przechowywane są w bibliotecznym zbiorze rękopisów; składają się na nie pochodzące z XVI-XVIII w. akta oryginalne, jak również kopie dokumentów (w tym jednego z 1398 r.) $)^{9}$. Ponadto w XVIII-wiecznym kodeksie zawierającym odpisy przywilejów różnych miast odnajdziemy również i wielickie, a nadto w fascykule zawierającym oryginały i kopie akt miast z lat 1452-1861 do Wieliczki odnoszą się dwa wypisy: z decyzji komisji podatkowej z 1717 r. oraz z mandatu króla Augusta III z 1742 r., w sprawie sporu między żupami wielickimi a miastem ${ }^{10}$.

W Archiwum Muzeum Żup Krakowskich także przechowywana jest dość duża liczba akt miasta Wieliczki. Obok oczywistej większości materiałów związanych ściśle z działaniem żup ${ }^{11}$, w których to spodziewać się możemy również wielu zapisów odnoszących się do spraw miejskich, znajdują się tu m.in. kopie dwóch dyplomów króla Augusta III wystawionych w 1739 r., dla miasta Wieliczki ${ }^{12}$, jak również w formie oryginałów i kopii kilkanaście dokumentów cechów wielickich (głównie królewskich potwierdzeń ich arty-

${ }^{8}$ Biblioteka Jagiellońska (dalej BJ), dypl. 3, 10, 13, 14, 15, 18, 20, 21, 22, 24, 25, 26, $31,37,40,48,49,50,51,54,55,58,59,67,75,76,86,91,100,102,103,187,188,189$, 193, 197, 203, 204, 205, 206, 210, 218, 219, 220, 221, 222, 255, 256, 257, 258, 261, 268, 269, 271, 301, 417, 410 .

9 BJ, rkp. 7554; przy czym większość ze znajdujących się tu aktów opublikowano w Kodeksie Dyplomatycznym Wielickim, w 1872 r.

${ }_{10}$ BJ, rkp. 972, k. 217-219, rkp. 7510, k. 62-64.

11 Archiwum to przechowuje historyczne materiały archiwalne żup wielickich, z lat 1492-1971. Zasób jego opracowywany był przez Kazimierza Dziwika oraz Marcina Marynowskiego i Leszka Rzepkę, których pracy owocem są trzy inwentarze archiwalne; zob. K. Dziwik, Katalog dokumentów Muzeum Żup Krakowskich z lat 1492-1777, Wieliczka 1979; idem, Katalog rękopisów Muzeum Żup Krakowskich z lat 1518-1971, Wieliczka 1988; M. Marynowski, L. Rzepka, Inwentarz Akt Salinarnych Wieliczki i Bochni z lat 1772-1918, Wieliczka 2004.

${ }_{12}$ Archiwum Muzeum Żup Krakowskich w Wieliczce (dalej AMŻK), sygn. D/III/23, $\mathrm{D} / \mathrm{III} / 24$. 
kułów i przywilejów) z lat 1570-1763 $3^{13}$. Z kolei z przechowywanych w tymże archiwum rękopisów wymienić należy księgę wójtowską z lat 1597-1608, w której spisano „inwentarz praw, przywileiow, processow, gruntow, domow, czynszow y prowentow do woitostwa wieliczkiego należących” w roku 1597, a także późniejsze przywileje, mandaty, ordynacje, a nadto księgę cechu krawieckiego w Wieliczce z lat 1620-1774, zawierającą rejestry przychodów i rozchodów cechu, wpisy wyzwolin oraz protokoły z posiedzeń cechu ${ }^{14}$. Ponadto bardzo wiele rozmaitych staropolskich dokumentów i aktów miasta Wieliczki odnajdziemy w odpisach w tzw. Tekach Fischera; stanowią one dzieło Andrzeja Fischera, pracownika salin, który w latach 1838-1856 gromadził materiały źródłowe do dziejów Wieliczki i Bochni oraz żup solnych ${ }^{15}$.

Na wielickie akta przechowywane w Bibliotece Naukowej Polskiej Akademii Umiejętności i Polskiej Akademii Nauk w Krakowie składają się cztery dyplomy pergaminowe z lat 1531, 1555, 1592 i 1684, zawierające królewskie potwierdzenia przywilejów i zatwierdzenia statutów wielickich cechów (ślusarzy oraz krawców i kuśnierzy) ${ }^{16}$, a nadto - w kilku woluminach - kopie innych staropolskich dokumentów i aktów odnoszących się do Wieliczki ${ }^{17}$. W zbiorach Biblioteki Fundacji Książąt Czartoryskich w Krakowie natomiast uwagę zwrócić należałoby przede wszystkim na dwa rękopisy: XVIII-wieczny dekret sądu asesorskiego w sporze o fundusze i domy w Wieliczce oraz „Prawa na dworek antiquitus dictus Baszta w Wieliczce 1659”, w którym zawarto wyciągi z ksiąg miejskich z lat 1568-1715, lustrację miasta i „Reformę praw i prowentów mieyskich wielickich" $\mathrm{z}$ drugiej połowy XVII w. ${ }^{18}$

Staropolskie wielickie archiwalia odnajdziemy ponadto $\mathrm{w}$ zasobach kilku jeszcze gromadzących historyczne materiały rękopiśmienne instytucji. W Bibliotece Zakładu Narodowego im. Ossolińskich we Wrocławiu odnotowujemy XVI- i XVII-wieczne kodeksy zawierające także i treści doty-

13 AMŻK, sygn. D/IV/1, D/IV/2, D/IV/3, D/IV/4, D/IV/6, D/V/3, D/V/4, D/V/14, D/VI/1, D/VI/2, D/VI/3, D/VI/4, D/VI/5, D/VI/7, D/VI/8, D/VI/13, D/XI/11.

${ }_{14}$ AMŻK, rkp. 10 i 11.

15 AMŻK, rkp. 30-42 (dalszych kilka jednostek z grupy „Tek Fischera” zawiera odpisy materiałów późniejszych, powstałych już po przejściu Wieliczki pod władzę zaborcza).

16 Biblioteka Naukowa Polskiej Akademii Umiejętności i Polskiej Akademii Nauk w Krakowie (dalej BPAN), dypl. 121, 148, 186, 273; przy czym odnajdziemy tu dodatkowo sporządzony w 1651 r. odpis jednego z tychże dyplomów (z roku 1531), zob. BPAN, rkp. 945.

17 BPAN, rkp. 439, k. 265-342, rkp. 440, k. 227-238, rkp. 1973, k. 90-95, rkp. 2859, rkp. 2900, k. 22-23.

18 Biblioteka Fundacji Książąt Czartoryskich w Krakowie, rkp. 2865, 2915. 
czące Wieliczki (m.in. znajdziemy w jednym z nich kopię potwierdzenia przywileju lokacyjnego z 1290 r. $)^{19}$, a ponadto przechowywany jest w Ossolineum odnoszący się do spraw granic Wieliczki dokument z 1578 r. $^{20} \mathrm{Z}$ kolei archiwum parafialne w Wieliczce posiada w swoim zasobie księgę śledczą urzędu radzieckiego (Acta inquisitionum offcii consularis Vieliciensis) z lat $1755-1760^{21}$. Wreszcie Józef Piotrowicz zwraca uwagę na staropolskie akta wielickie znajdujące się w archiwum w Dreźnie ${ }^{22}$.

Staropolskie materiały archiwalne miasta Wieliczki przechowuje się także, jak wyżej wspomniano, w zasobie Archiwum Państwowego w Krakowie. Stanowią tu one zasadniczo część zespołu aktowego, który w całości obejmuje archiwalia miasta Wieliczki z lat 1393-1945, z tym że ciekawe staropolskie materiały odnoszące się do spraw wielickich odnajdujemy również w innych przechowywanych w tymże archiwum zespołach. Zasadnicza część akt miasta Wieliczki została przejęta przez Archiwum Państwowe w Krakowie w 1948 r., kiedy to Zarząd Miejski w Wieliczce przekazał doń pierwszą ich większą partię ${ }^{23}$, chociaż nieco wielickich archiwaliów trafiło do krakowskiego Archiwum wcześniej. Już z początkiem XX w. Archiwum Akt Dawnych miasta Krakowa dysponowało pewną liczbą akt Wielicz$\mathrm{ki}^{24}$, z kolei jedną z ksiąg dziś wchodzących w obręb wspomnianego zespołu aktowego otrzymało w 1910 r. w darze od Józefa Kownackiego ${ }^{25}$, wreszcie inną grupę akt staropolskich przekazał Archiwum w okresie okupacji dr Heinz Göring, radca archiwalny ówczesnej dyrekcji archiwów w Generalnym Gubernatorstwie $^{26}$. Od 1948 r. Archiwum Państwowe w Krakowie przejmowało już z Wieliczki wyłącznie akta porozbiorowe i późniejsze ${ }^{27}$, po czym,

19 Biblioteka Zakładu Narodowego im. Ossolińskich we Wrocławiu (dalej BO), rkp 222, s. 4, rkp. 451, k. 157, rkp 673, s. 621-634.

20 BO, dypl. 326.

${ }^{21}$ Archiwum Parafii św. Klemensa w Wieliczce, rękopis niesygnowany; por. I. Pajdak, $K a-$ talog mikrofilmów Muzeum Żup Krakowskich Wieliczka, Wieliczka 1987, s. 47, nr 188.

22 Sächsisches Staatsarchiv, Polnische Sachen, nr 3538, cyt. za J. Piotrowicz, Wstęp, [w:] Wieliczka. Dzieje miasta, s. 10 i 15 przyp. 24.

${ }^{23}$ Archiwum Państwowe w Krakowie (dalej APKr), APKr 95, s. 43-47.

24 Sprawozdanie Dra St. Krzyżanowskiego dyrektora Archiwum Akt Dawnych miasta Krakowa za lata 1903 i 1904, Kraków 1905, s. 20.

25 Sprawozdanie Dra St. Krzyżanowskiego dyrektora Archiwum Akt Dawnych miasta Krakowa za rok 1910, Kraków 1911, s. 8.

${ }^{26}$ APKr, 29/117/6.

27 A. Litewka, Inwentarz zespołu Akt miasta Wieliczki z lat 1777-1945, Kraków 1975, maszynopis w APKr, s. 12-13. 
w latach 1972-1973 materiały z okresu 1777-1945 zostały uporządkowane i opracowane przez Aleksandra Litewkę $e^{28}$. Archiwalia wielickie dawniejsze, sięgające 1393 r. pozostały natomiast nieopracowane i objęte ewidencją tymczasową.

Aleksander Litewka, a także Józef Piotrowicz dali ogólną informację o staropolskich aktach Wieliczki, przechowywanych w Archiwum Państwowym w Krakowie ${ }^{29}$, jednak przeprowadzone w 2011 r. opracowanie lepiej ukazało ich treść. W ramach tegoż opracowania z istniejącą, uporządkowaną przez Aleksandra Litewkę częścią zespołu Akt miasta Wieliczki z lat 1777-1945 scalono znajdujące się w zasobie Archiwum akta, wytworzone w latach 1393-1785, jak również pewną jeszcze niewielką liczbę materiałów późniejszych ${ }^{30}$. Całemu zespołowi nadano nowe, zgodnie z obowiązującymi zasadami oparte o jego numer sygnatury, którymi zastąpiono dawne, funkcjonujące dla zespołu sygnatury MW, jak również inne tymczasowe, którymi oznaczone były archiwalia staropolskie. Część z nich wchodziła w obręb zbiorów dokumentów oraz rękopisów depozytowych i zewidencjonowana była pod sygn. Dok. Dep. 360, 361, 362, 363 oraz Dep. 427, 472, 473 i 474, inna część ujęta była w tzw. Inwentarzu Tymczasowym i oznaczona sygn. IT 258, 259, 281, 282, 283, wreszcie grupa akt stanowiła jednostkę o tymczasowej sygn. F 55. W przypadku trzech z wymienionych jednostek archiwalnych, tj. IT 282, IT 283 i F 55 akta z racji na ich zróżnicowanie tematyczne i chronologiczne rozdzielono na nowe jednostki, pozostałe natomiast zachowano, uściślając jednak opisy ich zawartości i weryfikując lub określając chronologię akt.

Archiwalia staropolskie, wchodzące w obręb zespołu Akt miasta Wieliczki to materiały pochodzące zasadniczo z lat 1393-1785, choć posteriora sięgają 1867 r. W ramach przeprowadzonego opracowania akta te uporządkowano według schematu, który z racji na szczątkowość zachowania stanowi

${ }^{28}$ Owocem tej pracy jest wyżej wymieniony inwentarz zespołu.

29 A. Litewka, op. cit., s. 24-26; J. Piotrowicz, Wstęp, s. 9-11.

$30 \mathrm{O}$ uporządkowaniu akt staropolskich Wieliczki i ewidencyjnym scaleniu ich z resztą zespołu Akt miasta Wieliczki zdecydował fakt, iż jak przyjmuje się w polskiej archiwistyce, zespoły akt miast obejmują zasadniczo przechowywane w archiwalnych zasobach akta miejskie, wytworzone w okresie od XIII w. (zatem od początków samorządu miejskiego) do 1945/1950 r., por. Wytyczne Naczelnego Dyrektora Archiwów Państwowych z 1 sierpnia 1958 r. w sprawie porzadkowania akt miejskich, [w:] Zbiór przepisów archiwalnych wydanych przez naczelnego dyrektora archiwów państwowych w latach 1952-2000, opr. M. Tarakanowska i E. Rosowska, Warszawa 2001 , s. 261-262. 
próbę podziału rzeczowego dokumentacji ${ }^{31}$. Podzielono mianowicie staropolskie akta miasta Wieliczki na następujące grupy: dokumenty, księgi, akta dotyczące miasta, akta dotyczące mieszczan, akta szpitala św. Ducha, akta cechów (zewidencjonowano je jako odrębne podserie w ramach serii akt staropolskich).

W obręb zespołu Akt miasta Wieliczki wchodzi kilka dokumentów w ścisłym tego słowa znaczeniu. Składają się na nie cztery dyplomy królewskie oraz jeden dokument wystawiony przez sędziego i podsędka ziemi krakowskiej. Najdawniejszy z wymienionych pochodzi z 11 marca 1393 r. i jest to właśnie ów dokument sędziego i podsędka. Sędzia Drogomir i podsędek Michał poświadczają w nim sprzedaż przez Jaśka z Czulic rajcom wielickim karczmy w Marcinkowicach ${ }^{32}$.

Kolejnym chronologicznie jest dokument królewski - wystawiony przez Władysława Jagiełłę 28 sierpnia 1428 r. w Nowym Mieście Korczynie. Król odnosi się tu do mającego miejsce łamania wcześniejszego postanowienia królewskiego, zakazującego zakładania karczm w odległości bliższej niż pół mili od miasta i poleca wojewodzie sandomierskiemu Mikołajowi z Michałowa oraz każdemu następnemu krakowskiemu staroście przestrzegać rzeczonego postanowienia i nie zezwalać na wyszynk napojów w pobliżu miasta ${ }^{33}$. Pozostałe dyplomy królewskie są już znacznie późniejsze. Z 1706 r. pochodzi wydany w Krakowie dokument króla Augusta II, którym wystawca zabrania wojskom Rzeczypospolitej oraz posiłkującym je saskim, moskiewskim i kozackim popasów i stacji wojskowych $\mathrm{w}$ Wieliczce. Jest to dokument papierowy, opatrzony wyciśniętą przez papier pieczęcią mniejszą koronną. 9 marca 1715 r. wystawiony został kolejny z interesujących nas dokumentów, rów-

31 Zgodnie z wyżej wspomnianymi wytycznymi naczelnego dyrektora archiwów państwowych z 1958 r. aktom miast powinno nadać się układ zgodny z układem kancelaryjnym kancelarii, w której powstały, lecz w przypadku szczątkowych zespołów dopuszcza się wprowadzenie układu rzeczowego.

32 APKr, 29/117/1; dokument ten został wydany drukiem, zob. Kodex Dyplomatyczny Wielicki, s. 13-14. Jasiek (Jan) z Czulic poświadczony jest źródłowo od 1385 r., natomiast zmarł w 1389 r., a znany jest m.in. jako komornik sądu ziemskiego krakowskiego, zob. Stownik historyczno-geograficzny województwa krakowskiego w średniowieczu, red. F. Sikora i in., Kraków 1980-2006, cz. 1, s. 476-477.

33 APKr, 29/117/2. Mikołaj Białucha z Michałowa h. Poraj, urodzony ok. roku 1370, zmarły w 1438, był m.in. w latach 1410-1430 wojewodą sandomierskim i w latach 1418-1438 starostą krakowskim, zob. A. Kamiński, Mikołaj z Michałowa i Kurozwęk, PSB, 1976, t. 21, s. 123-126 oraz Urzędnicy małopolscy XIII-XV wieku, red. A. Gąsiorowski, Wrocław-Warszawa-Kraków 1990, nr 983, 1291, 1293. 
nież Augusta II. Król transumuje w nim wydane przez poprzednich monarchów przywileje dla miasta Wieliczki i zatwierdza uprawnienia, jakie Wieliczka posiada na mocy dawniejszych królewskich przywilejów i sejmowych konstytucji. Podobnej treści jest najmłodszy z przechowywanych w krakowskim Archiwum odnoszących się do Wieliczki dyplomów królewskich - wystawiony 24 kwietnia 1765 r. w Warszawie, przez króla Stanisława Augusta, również stanowiący zatwierdzenie przywilejów poprzednich królów dla Wieliczki (przedłożonych mu przez rajcę Wojciecha Piątkowskiego i syndyka miasta Szczepana Czekayskiego) ${ }^{34}$.

Z XVIII w. pochodzi kilka zachowanych kopii i regestrów przywilejów wielickich. Obejmują one dokumenty z lat 1423-1777, przy czym część z nich dotyczy spraw żup. Przechowywana wspólnie z tymi materiałami korespondencja, prowadzona w latach 1776-1836 z władzami austriackimi w sprawie zatwierdzenia przywilejów Wieliczki sugeruje, w jakim celu zostały one zebrane ${ }^{35}$. Podobna w treści jest jeszcze grupa spisów przywilejów i innych dokumentów miasta. Najdawniejszy z nich jest niedatowany, prawdopodobnie pochodzi z XVII w.; obejmuje przywileje z lat 1290-1676. Kolejny spis wykonany został w 1758 r. przez Szczepana Czekayskiego i ujmuje, jak czytamy w nagłówku, „przywileje, dekrety i inne munimenta miejskie”, które w 1758 r. nie zostały przesłane do Warszawy (najpewniej w związku ze staraniami o potwierdzenie królewskie, uzyskane następnie w 1765 r.), a które teraz Czekayski składa „ad Archiwum Civile”. Jeszcze jeden spis to wykaz przywilejów i innych dokumentów, sporządzony w 1867 r., przy okazji wysyłki archiwaliów do lwowskiej siedziby Namiestnika hr. Agenora Gołuchowskiego, w celu ich opracowania (niewątpliwie w związku z pracami wydawniczymi, których zwieńczenie stanowił Kodex Dyplomatyczny Wielicki). To właśnie wymienione tu spisy dokumentów przekazane zostały do Archiwum podczas okupacji, przez radcę archiwalnego Heinza Göringa ${ }^{36}$.

Wielickich ksiąg miejskich zachowana jest, jak już wyżej wspominano, nikła ilość. W zasobie Archiwum Państwowego w Krakowie przechowywane są dwie księgi wójtowsko-ławnicze i fragmenty kolejnej ławniczej oraz

${ }^{34}$ APKr, 29/117/3-5; ostatni z wymienionych dokumentów został ogłoszony drukiem w Kodeksie Dyplomatycznym Wielickim, z tym że z nieznanej kopii lub tłumaczenia, zob. Kodex Dyplomatyczny Wielicki, s. 164-169.

35 APKr, 29/117/7.

36 APKr, 29/117/6. Odnośnie do Kodeksu Dyplomatycznego Wielickiego por. przyp. 6. 
radzieckiej ${ }^{37}$. Najdawniejsza z wymienionych jest księga wójtowsko-ławnicza, spisana w latach 1557-1627. Obejmuje ona zasadniczo zapisy dotyczące spraw własności i dziedziczenia, przy czym część jej zajmują odtworzone wpisy wcześniejsze; księgę tę zaczęto prowadzić po pożarze miasta w 1556 r. i na podstawie ocalałych dokumentów oraz zeznań świadków odtwarzano dawniejsze, sięgające roku 1436 zapisy ${ }^{38}$. Druga z rzeczonych ksiąg wójtowskoławniczych to, jak informuje jej tytuł, akta sporów i zapisów sądu miejskiego wielickiego; pochodzi ona $\mathrm{z}$ lat $1597-1619^{39}$. Z kolei zachowane fragmenty księgi ławniczej i radzieckiej to nadpalone szczątki pochodzące z różnych lat, dla których tylko częściowo udało się ustalić chronologię. W pierwszym przypadku zachowały się karty z lat 1599, 1602-1607, 1609-1616, 1618, $\mathrm{w}$ drugiej z wymienionych ksiąg natomiast - z roku 1597, 1598, prawdopodobnie 1599 oraz 1603, a także pewna liczbą kart, dla których znane są tylko miesiące, lat zaś nie ustalono. Niestety ze względu na znaczny stopień zniszczenia i fragmentaryczność ksiąg ławniczej i radzieckiej ich przydatność badawcza nie jest znacząca, choć wobec ogólnej szczątkowości zachowanych akt wielickich nie można ich pominąć. Pewną ciekawostką, z jaką spotykamy się w obu księgach, są znajdujące się w nich dekoracje. We fragmentach księgi ławniczej odnajdujemy przy jednym z inicjałów rysunek postaci, w szczątkach księgi radzieckiej z kolei jedna ze stron ozdobiona jest barwną bordiurą;

${ }_{37}$ Z początkiem XVII w. mieszczanie wieliccy zdołali skupić w swoich rękach wójtostwo wielickie. Rada miejska najpierw, stopniowo w latach 1413-1545 wykupiła je, i później, najwyraźniej wobec trudności finansowych wydzierżawiła, a w następstwie pod koniec XVI w. znowu utraciła, jednak dzięki nieustępliwej walce mieszczanie wieliccy w 1609 r. odzyskali wójtostwo. W latach 1545-1595 i znowu od 1609 r. miasto miało wójta sądowego, tj. wybieranego spośród byłych rajców przewodniczącego sądu ławniczego, stąd też wspólnie prowadzono księgi ławnicze i wójtowskie, natomiast właśnie śladem konfliktu między mieszczaństwem a ówczesnym wójtem Janem Szczerbicem i jego ojcem Pawłem jest sporządzona przy jego okazji księga wójtowska z lat 1597-1608, przechowywana w Archiwum Muzeum Żup Krakowskich. W kwestii zabiegów wielickich mieszczan o przejęcie wójtostwa zob. J. Piotrowicz, Dole i niedole, s. 125-130 oraz F. Sikora, Wójtostwo wielickie w średniowieczu, „Annales Academiae Paedagogicae Cracoviensis. Studia Historica” 2004, t. 3, s. 209, 221.

38 APKr, 29/117/8.

39 APKr, 29/117/9. Obie zachowane księgi ławniczo-wójtowskie pochodzą częściowo z okresu, gdy wójtostwo wielickie znajdowało się w rękach Szczerbiców i fakt ten w drugiej księdze, rozpoczętej w ich czasach został uwidoczniony. Na jej przedniej okładce wytłoczono herb rodziny - Jelita, z napisem w otoku PAULUS SCZERBICZ SECRETARIUS REGIUS, a na pierwszej stronie wypisano imię ówczesnego wójta Jana Szczerbica i ponownie jego ojca Pawła; z racji na niepełnoletność Jana, to jego ojciec administrował przez pewien czas wójtostwem, zob. J. Piotrowicz, Dole i niedole, s. 128-129. 
ujrzymy tu scenę z polowania w nagłówku, wizerunki zwierząt, czy też raczej fantastycznych stworzeń z boków strony i pod tekstem, nadto ornamenty roślinne w bocznych obrzeżeniach ${ }^{40}$.

Kolejna grupa zachowanych materiałów to stosunkowo duża liczba różnego rodzaju luźnych zazwyczaj akt, odnoszących się do problemów miasta Wieliczki, jak również rozmaitych spraw jego mieszkańców. Ewidencyjnie podzielone zostały one na dwie podserie, tj. właśnie dotyczące miasta i mieszkańców. W pierwszej z nich ujęto materiały poświęcone stosunkom prawnym, nieruchomościom miejskim, sprawom podatkowym. Odnajdujemy tu protokoły królewskiego sądu komisarskiego, który w 1743 r. powołany został do zbadania stanu dóbr miejskich i stosunków prawnych panujących w Wieliczce, sporządzone w XVI i XVII w. kopie dokumentów z lat 1398-1661, odnoszących się do spraw granic nieruchomości miejskich, XVIII-wieczne akta dotyczące wójtostwa wielickiego oraz wsi miejskiej Grabówki, m.in. trzy jej inwentarze $\mathrm{z}$ lat 1740,1742 , 1755, a nadto akta podatkowe i rachunkowe - rejestr podatkowy z 1671 r., kopie królewskich dokumentów w sprawie nadużyć podatkowych, dotykających mieszczan wielickich (Jana III z 1683 r., skierowany do władz miasta, oraz Augusta III z 1737 r., do wojewody, starosty i podkomorzego krakowskiego), XVIII-wieczne rachunki miejskie ${ }^{41}$.

$\mathrm{Na}$ akta dotyczące spraw mieszczan wielickich składają się przede wszystkim ekstrakty z ksiąg wpisów, dotyczące głównie spraw majątkowych spornych i niespornych, a także innych spornych z udziałem mieszkańców Wieliczki. Znajdują się tu wyciągi z akt radzieckich, ławniczych, wójtowskich, podkomorskich i burgrabiowskich wielickich, a także z akt Sądu Wyższego Prawa Niemieckiego na zamku w Krakowie, Asesorii Koronnej, ksiąg wójtowskich i ławniczych krakowskich, podkomorskich i grodzkich krakowskich, jak również radzieckich warszawskich. Ponadto odnajdziemy w tej grupie inne jeszcze różnorodne materiały, jak supliki, inwentarze majątkowe, kontrakty kupna, skrypty, zeznania mieszczan, wreszcie mieszczańskie rachunki ${ }^{42}$. Wśród najróżniejszych akt specjalną uwagę zwrócić można choćby na niedatowane wprawdzie, ale sporządzone najpewniej ok. 1767 r. „punkta” przygotowane pod kątem spodziewanej w Wieliczce Komisji Dobrego

\footnotetext{
40 APKr, 29/117/10-11.

${ }^{41}$ APKr, 29/117/12 - 17.

${ }^{42}$ APKr, 29/117/18 - 32 .
} 
Porządku ${ }^{43}$, czy też materiały z lat 1742-1753, związane z działaniami Komisji królewskiej dla miasta Wieliczki, rozstrzygającej m.in. w sporze rajców z Wojciechem Konopką i Franciszkiem Godeckim ${ }^{44}$. W sumie na powyższe archiwalia dotyczące mieszczan wielickich składają się materiały pochodzące $\mathrm{z}$ lat $1614-1788$.

Wśród zachowanych wielickich akt wymienić trzeba jeszcze księgę pozostałą po miejskim szpitalu ubogich pod wezwaniem św. Ducha; szpital ten powstał w 1363 r. z fundacji króla Kazimierza Wielkiego, natomiast później pozostawał pod zwierzchnictwem i opieką wielickiej rady miejskiej ${ }^{45}$. Zachowana księga to „Regestra szpitala wielickiego” spisane w latach 1537-1713. Ze względu na różnorodną i ciekawą treść stanowić może ona cenne źródło do poznania dziejów rzeczonego szpitala. Teoretycznie poświęcona jest dwóm zagadnieniom - przychodom i wydatkom szpitalnym, ale umieszczono tu m.in. inwentarz nieruchomości szpitala z 1639 r., opis wyposażenia kaplicy szpitalnej z 1695 r., rejestr ksiąg i obrazów szpitalnych z 1713 r. ${ }^{46}$ To właśnie tę księgę podarował Archiwum w 1910 r. dr Józef Kownacki.

Zasygnalizować należy także obecność w zasobie Archiwum Państwowego w Krakowie szczątkowo zachowanych akt cechów wielickich. Obok szerzej znanej księgi cechu bednarzy, tj. „Regestru zapisowania chłopców do rzemiosła cechu bednarskiego wielickiego", rozpoczętego przez starszego ce-

${ }^{43}$ APKr, 29/117/31. Komisję Dobrego Porządku dla Wieliczki powołano podczas sejmu delegacyjnego w latach 1767-1768, zob. M. Bogucka, H. Samsonowicz, Dzieje miast i mieszczaństwa w Polsce przedrozbiorowej, Wrocław-Warszawa-Kraków-Gdańsk-Łódź 1986, s. 577.

${ }_{44}$ APKr, 29/117/30. Na temat tego sporu mowa również w Protokołach sądu komisarskiego z 1743 r., zob. APKr, 29/117/12; por. Z. Wojas, Wieliczka od połowy XVII wieku do roku 1772, [w:] Wieliczka. Dzieje miasta, s. 175.

${ }_{45}$ Z inicjatywą utworzenia szpitala wystąpili w 1363 r. tak rajcy wieliccy, jak i żupnik oraz żupne bractwo tragarzy i król niebawem istotnie powołał w Wieliczce tę instytucję. Pierwotnie służyć miała ona najpewniej przede wszystkim rzeczonym tragarzom, będącym grupą pracowników kopalni najliczniejszą, a równocześnie słabo opłacaną (z czasem jednak ten priorytet zaniknął). Zwierzchnictwo i opieka nad szpitalem, choć przeznaczony był on zasadniczo dla pracowników żup, spoczywały na radzie miejskiej wielickiej, która do zarządu nad jego mieniem i gospodarką powoływała prowizorów. Na utrzymanie szpitala król Kazimierz przeznaczył natomiast dochód z pracy dwóch otroków (tj. najemnych kopaczy soli) w wyrobiskach każdego z szybów wielickich. Na temat tegoż szpitala zob. J. Piotrowicz, Dzieje miasta Wieliczki w wiekach średnich, [w:] Wieliczka. Dzieje miasta, s. 86.

${ }^{46}$ APKr, 29/117/33. 
chowego Jana Antoniego Posockiego w roku 1689 i kontynuowanego aż do $1808^{47}$, wymienić trzeba tu jeszcze niewielką, ale różnorodną liczbę akt różnych cechów, jaka przechowywana była wspólnie z innymi aktami miejskimi. Składają się na nie odpisy z ksiąg cechowych i sądowych oraz inne luźne akta dotyczące różnego typu spraw, jak spory (np. między wielickimi rzeźnikami i kijakami w 1717 r.), długi, wyderkaufy, a także akta rachunkowe. Najwięcej znajdziemy tu materiałów cechu bednarzy, ale są i akta krawców, kuśnierzy, wspomnianych rzeźników, jak również żupnego bractwa tragarzy. Materiały te pochodzą z lat $1602-1769^{48}$.

Wobec przepadku niemal wszystkich ksiąg miejskich, dla uzyskania obrazu Wieliczki przed wiekami, poznania jej dawnej kondycji gospodarczej, sytuacji prawnej, panujących w mieście stosunków niewątpliwie sięgać trzeba do takich jak te omówione powyżej różnego typu szczątkowo zachowanych akt. W zasobie Archiwum Państwowego w Krakowie takowe odnajdujemy zasadniczo w zespole Akt miasta Wieliczki, jednakże nie jest to jedyny zespół archiwalny, w którym trafić możemy na odnoszące się do Wieliczki w okresie przedrozbiorowym zapisy.

Za szczególnie przydatne dla badań nad dziejami stosunków miejskich w Wieliczce uznać należy jeszcze przechowywane w Archiwum Państwowym w Krakowie, stanowiące odrębny zespół księgi sądu podkomorzego krakowskiego, zawierające odwołania od wyroków ławy i rady miasta Wieliczki. Składa się na nie w sumie czternaście ksiąg z lat 1570-1591, 1698 i 1702$-1779^{49}$, w których obok ogólnych spraw związanych z jurysdykcją podkomorzego krakowskiego w Wieliczce, jak odpis dekretu królewskiego ją ustalającego z roku $1583^{50}$, ogłoszenia tejże jurysdykcji, czy ordynacje oraz wpisów odnoszących się do sporów i innych spraw mieszczan wielickich, w tym również kwestii majątkowych i mieszczańskich akt rachunkowych znajdują się np. królewskie zatwierdzenia praw i przywilejów Wieliczki z ich transumptami $^{51}$, a poza tym różnorakie zapisy dotyczące spraw miejskich Wielicz-

${ }_{47}$ APKr, 29/199/46; por. I. Pajdak, op. cit., s. 57-58, nr 236 oraz J. Piotrowicz, Wstęp, s. 15 przyp. 25 .

48 APKr, 29/117/34.

49 APKr, Varia 1-6; IT 100-107.

50 APKr, Varia 1, s. 86-89.

51 Potwierdzenie Zygmunta Augusta z 1570 r., zob. APKr, Varia 2, s. 1455-1472 oraz Augusta II z 1715 r., zob. ibidem, s. 879-892. 
ki: wyborów do rady miejskiej, zagadnień gospodarczo-finansowych (w tym czynszów, opłat, podatków), spraw wójtostwa, cechów etc. ${ }^{52}$

Wśród zespołów aktowych, na jakie jeszcze w zasobie krakowskiego Archiwum Państwowego powinniśmy tu zwrócić uwagę, wymienić trzeba przede wszystkim Księgi grodzkie krakowskie. Ze znajdujących się tu licznych wpisów tyczących się spraw wielickich wymienić można choćby takie jak oblaty dokumentów królewskich, zapisy dotyczące miejskich przywilejów, podatków, taks i miar, jarmarków, rozbojów i rozruchów, czy wreszcie wpisy odnoszące się do spraw cechowych. Niektóre stanowią świadectwa dziejowych wydarzeń dotykających Wieliczkę, jak np. uwolnienie mieszczan wielickich od podatków i ciężarów, które ogłosił król Zygmunt August w 1556 r., w związku z pożarem, jaki właśnie nawiedził miasto ${ }^{53}$, czy też sprawa z 1685 r. o rabunki dokonane z udziałem Szwedów ${ }^{54}$. Ponadto wśród ciekawszych wymienić można spis domów Wieliczki z 1706 r. oraz rejestr budynków spalonych w latach $1705-1706^{55}$. Poza księgami grodzkimi godne odnotowania są jeszcze księgi Sądu Wyższego Prawa Niemieckiego na zamku w Krakowie z lat 1390-1794 oraz Sądu Sześciu Miast z lat 1524-1725 56; oba te sądy, powołane przez króla Kazimierza Wielkiego w 1356 r., stanowiły instancje odwoławcze od wyroków lokalnych małopolskich sądów prawa niemieckiego, a nadto w obu z nich zasiadali przedstawiciele miasta Wieliczki ${ }^{57}$. Znajdują się wreszcie pewne staropolskie wielickie archiwalia w przechowywanych w Archiwum Państwowym w Krakowie Tekach Schneidra, jednakże liczba tego typu materiałów jest tu niewielka, akta zgromadzone przez Antoniego Schneidra pochodzą bowiem w przeważającej większości z okresu porozbiorowego ${ }^{58}$.

Szczątkowy stan zachowania staropolskich akt miasta Wieliczki nie daje nam możliwości odtworzenia początków kancelarii miejskiej. Za Marianem Friedbergiem stwierdzić należy, że niekoniecznie równocześnie z otrzy-

${ }^{52}$ M.in. również i tu natrafiamy na ślad wspomnianej już wyżej walki, jaką z początkiem XVIII w. toczyli w obronie interesów swego cechu wieliccy rzeźnicy, zapisano bowiem w księgach ich wystąpienie przeciwko kijakom w 1720 r., zob. APKr, Varia 3, s. 55.

53 APKr, Castr. Crac. 75, s. 462.

54 APKr, Castr. Crac. 925, s. 744, 937.

55 APKr, Castr. Crac. Rel. 132, s. 1311-1317 oraz Castr. Crac. Rel. 133 B, s. 765.

56 APKr, SWPM I 1-74 oraz SWPM II 1-6.

57 J. Piotrowicz, Dzieje miasta Wieliczki, s. 79.

58 Staropolskie akta wielickie odnajdziemy w dwóch z Tek Schneidra, tj. APKr, TSchn. 1683, s. 75-87 oraz TSchn. 1684, s. 681-682. 
maniem praw miejskich datuje się powstanie kancelarii. Na gruncie polskim ich początki i rozwój wiążą się ściśle z powstaniem samorządów w następstwie lokacji na prawie niemieckim, jednak zazwyczaj świadectwa funkcjonowania takowych instytucji w miastach są o kilkadziesiąt lat późniejsze od przeprowadzenia lokacji. Najpewniej kształtowały się one wraz z urzędami, które obsługiwały ${ }^{59}$; choć zarazem zauważyć trzeba, że przynajmniej w przypadku większych ośrodków kancelarie mogły powstawać już zaraz po przeprowadzeniu lokacji ${ }^{60}$.

Niestety w przypadku Wieliczki akta, z których otrzymujemy informację o miejskiej kancelarii, są znacznie późniejsze aniżeli lokacja, jakiej dokonano w 1290 r., w zasadzie bowiem pochodzą one dopiero z drugiej połowy XVI w. Istnienie samej rady miejskiej, przy której domyślać możemy się kancelarii, stwierdzamy bez wątpliwości w 1356 r. $^{61}$, jednak oczywiste jest, że istniała już ona wtedy od dłuższego czasu, natomiast informację o pisarzu miejskim otrzymujemy po raz pierwszy dopiero w 1557 r.; był nim wtedy rajca Feliks Łowicki. Później, w 1597 r. jako pisarz poświadczony jest Stanisław Kotlicki, a Adam Wiktoryn Skąpski sprawował wówczas zwierzchnictwo nad urzędem notarialnym ${ }^{62}$.

Jak zauważa Marian Friedberg, z funkcjonowaniem kancelarii wiąże się także istnienie pieczęci ${ }^{63}$. W tym przypadku mówić możemy o świadectwie dawniejszym, niż w przypadku poświadczenia w źródłach pisarzy miejskich, najstarsza pieczęć miasta Wieliczki pochodzi bowiem jeszcze z XV w. ${ }^{64}$; choć i tak oczywiście również ten czas nie wyznacza początków miejskiej kancelarii, która z pewnością istniała już w XIV w. Działalność rozpoczęła może w początkach tego stulecia albo nawet, jeśli trafne są spostrzeżenia o począt-

59 M. Friedberg, Kancelaria miasta Krakowa do połowy XVIII w., „Archeion”, 1955, t. 24, s. 280.

${ }^{60}$ Taki pogląd o powstaniu m.in. kancelarii miasta Krakowa wyraża Bożena Wyrozumska, która za Stanisławem Kurasiem zwraca uwagę na funkcje organizacyjno-porządkowe, jakie przynajmniej w początkach istnienia pełniły kancelarie i stwierdza niewątpliwą konieczność istnienia tego typu urzędu wspomagającego działalność władz miejskich od chwili ich ukonstytuowania się, a co za tym idzie powstanie krakowskiej kancelarii odnosi do roku 1257, zob. B. Wyrozumska, Kancelaria miasta Krakowa w średniowieczu, Kraków 1995, s. 18-19.

${ }^{61} \mathrm{~J}$. Piotrowicz, Dzieje miasta Wieliczki, s. 80.

62 APKr, 29/117/8-9; por. J. Piotrowicz, Dole i niedole, s. 132.

${ }^{63}$ M. Friedberg, op. cit., s. 300.

${ }^{64}$ H. Seroka, Herby miast małopolskich do końca XVIII wieku, Warszawa 2002, s. 150-151. 
kach miejskich kancelarii wyrażone przez Bożenę Wyrozumską, pod koniec XIII w. ${ }^{65}$

Podsumowując stwierdzić wypadnie, iż niestety wydarzenia dziejowe sprawiły, że dzisiejszy stan zachowania źródeł do najdawniejszych przedrozbiorowych dziejów znaczącego przecież miasta, jakim przez kilka wieków była Wieliczka daleki jest od takiego, jakiego życzylibyśmy sobie. Nikła część akt wielickich, która się do naszych czasów dochowała musi wystarczyć nam do wypracowania obrazu dziejów miasta; w znacznym stopniu posłużyły już one zresztą badaczom do tego celu, niemniej jednak niewątpliwie wciąż zachowane akta miasta Wieliczki wiele mogą nam o jego dziejach powiedzieć, przy czym szczególnie uwagi warte są tu w niewielkich stopniu wykorzystane w nauce, a niedawno opracowane wielickie akta z zasobu Archiwum Państwowego w Krakowie.

W ramach staropolskiej części zespołu Akt miasta Wieliczki, obok kilku cennych dokumentów oraz zapisów odnoszących się do wielickich przywilejów, szczególnie interesująco przedstawiają się stosunkowo najliczniejsze akta w większości luźne, tyczące się spraw miasta i mieszczan. Są to co prawda materiały zachowane wyrywkowo, ale ze względu na swoją różnorodność dać mogą pewien szerszy obraz stosunków społecznych i spraw majątkowych tak miasta, jak i jego mieszkańców, szczególnie w wiekach XVII i XVIII. Ponadto warta specjalnej uwagi jest księga szpitala wielickiego, mogąca stanowić ważne źródło do badań nad dziejami tegoż szpitala, a przede wszystkim jego uposażenia, bowiem majętności szpitalne opisano w nich szczegółowo. Z pewnością te, ale i inne przechowywane w krakowskim Archiwum Państwowym staropolskie wielickie archiwalia uzupełniłyby naszą wiedzę o przeszłości ważnego ośrodka miejskiego, jakim przez wieki była Wieliczka, o sporo elementów, tak o charakterze szczegółowym, jak również może ogólniejszym. Stanowią one zatem możliwą podstawę do wnikliwszych badań historycznych.

${ }^{65}$ Zob. przyp. 60. 